\title{
Juan Carlos Moreno Romo, 2014 \\ Filosofía del ArRabal \\ Barcelona: Editorial Anthropos, 144 pp.
}

\begin{abstract}
Cuando el valor es una pasión, y no un hábito o inclinación natural, es cierto calor o agitación que dispone el alma poderosamente a ejecutar las cosas que quiere hacer, cualquiera que sea su naturaleza. El atrevimiento es una especie de valor que dispone el alma a ejecutar las cosas más peligrosas.
\end{abstract}

Descartes. Las pasiones del alma

Arrabal (del árabe arrabad): barrio fuera del recinto de la población. Como sinónimo encontramos la palabra suburbio que es un sitio extremo de un poblado. El título de este libro es una provocación para poder pensar al margen, quizá a un costado o afuera de las versiones oficialistas entre tanto canónicas, de aquello que se le ha denominado en un pasado reciente: el "discurso filosófico".

Estar fuera o al margen no implica no estar inserto en el mundo, sino que esa distancia nos permite contemplar desde otros lugares el centro. Habitar en la periferia de ese discurso filosófico quizá nos permita viajar y transitar sin arraigo, sin identidad por las diversas latitudes que trazan las cartografías del pensamiento. El texto del profesor Moreno Romo es una invitación a cuestionar, en cierta medida, aquella filosofía que se anuncia y se encuentra como en los escaparates de un centro comercial, o aquella filosofía conjurada por las casas editoriales y las trampas inmediatas del mundo virtual. Es decir, filosofías de moda, pasajeras y que son aquellas -y en demasiadas ocasiones- donde la academia se eclipsa dejando problemas y debates demasiado trasnochados.

Encontramos en esta filosofía del arrabal un trabajo minucioso de re-escrituración de textos que han sido presentados como ponencias y que han tomado la materialidad del libro; estamos frente a una compilación de textos que tienen la virtud de que ya han sido expuestos y debatidos frente a un auditorio.

Uno de los problemas que se encuentran en esta filosofía del arrabal es precisamente el problema de la traducción de textos filosóficos 
y que curiosamente abre el problema de la tradición, pues el canon de la filosofía alemana, por apelar al mundo griego como una ÜrKultur o cultura originaria, ha casi borrado la tradición latina.

La traducción de los textos denominados clásicos no es un asunto de identidad nacional, es un problema hermenéutico, es decir es una aporía textual. Curiosamente, el lenguaje modela el pensamiento. Así, cuando realizamos una lectura traducimos, y entre tanto nos transformamos en intérpretes de un texto, que plasma una voz, al menos un sonido.

Por otro costado el pasaje de una lengua a otra lleva a homologar signos escriturales, y en ese esfuerzo y tensión del traductor, que se enfrenta al lenguaje y a otra lengua, se produce una pérdida ante la imposibilidad de encontrar una palabra, un signo cercano, o una emulación parecida, pero jamás la palabra exacta. Pensemos un poco en los regionalismos, como el lunfardo o las transposiciones lingüísticas y vocablos que emergen de lo popular y de los estados de indigencia. Al no encontrar el sinónimo, será curiosamente a partir de ese detalle que se inaugure un texto, entre tanto un sentido. La traducción siempre será otro texto, la traducción es un relevo, una secuencia del texto original.

Sócrates hablaba; Platón escribía y transcribía la voz de su maestro: el aliento y el hablar quizá sea uno de los primeros artificios teratológicos y racionales de la cultura occidental, quizá Platón lo traducía al momento de modular haciendo un fade out a la voz de su maestro y matizar esos fonemas en escritura.

Las traducciones que se han realizado de la Grecia Antigua, quizá, como replicaba Jean Bollack son textos que son de todos pero a la vez de nadie, precisamente por los efectos de traducción. Entre tanto la Odisea ya no pertenece a Homero, sino al naufragio que es la existencia misma, o a la posibilidad de que habitemos como en el título de un film y en las imágenes de Lost in Translation o escuchemos a Glenn Gould traducir notaciones musicales de la escritura de Bach en las Variaciones Goldberg. Retomando a Pascal Quignard: "hay en toda música una llamada que yergue, una conminación temporal, un dinamismo que agita, que empuja a desplazarse, a levantarse y a dirigirse hacia la fuente sonora". 
La Biblia y sus demasiadas versiones, las interpretaciones latinas de la cultura griega que se generaron a causa de la traducción son interpretaciones y versiones, supuestos que en ocasiones nos permiten nombrar el mundo. Pero nombrar no es traducir. Quizá Babel sea el signo contundente de no poder agotar las traducciones, es decir de mostrar la existencia de lo imposible, a pesar del cansancio de Atlas y de soportarse a sí mismo.

Gutenberg produjo una revolución, que consistió en aglutinar caracteres de acero y tinta, y que en cierta medida fue el gesto que propició que algunos copistas perdieran su oficio, por la impresión de biblias. El siguiente acto herético revolucionario fue llevado a cabo por Lutero, simplemente por traducir la Biblia a la lengua alemana. De esta manera podríamos considerar el acto de traducir como algo inaugural, como un acto creativo, como la apertura de una tradición generadora de imágenes, así las palabras. A la vez, la traducción permite que los textos viajen, que arriben a otras lenguas, hacia algunos lectores (cabe recalcar que el autor del libro también tiene el oficio de traductor).

La insistencia en postular una tradición latina es algo latente que se encuentra dentro de esta filosofía del arrabal. Los nombres de Suárez, Descartes, Unamuno y hasta Alquié parecen personajes dignos del arrabal al estar como out-siders de la filosofía y al iniciar a la vez una tradición, por tanto, algo más cercana a nosotros. Por eso de lo que se trata es de indagar y cuestionar la Modernidad desde referentes que apelen a lo latino y que permitan criticar los problemas planteados durante el siglo de las luces, es decir, provocar otra lectura con otros referentes y cuestionar si somos un efecto de los valores generados por la Revolución Francesa.

Filosofía del arrabal es, sin duda, un texto que da vigencia a los problemas filosóficos que tienen que ver con este presente que también es el nuestro.

Carlos Alberto García

Universidad Autónoma de Querétaro, México

carlos.garcia@uaq.mx 